\title{
ESTIMATING THE POTENTIAL SUSTAINABILITY OF GEOSYSTEMS IN CONDITIONS OF ANTHROPOGENIC IMPACTS (A CASE STUDY OF SARYSU BASIN, KAZAKHSTAN)
}

\author{
OZGELdinOVA, ZH. O. ${ }^{*}$ - JANALEYEVA, K. M. ${ }^{1}$ - DAVID, L. D. ${ }^{2}-$ MuKAYEV, ZH. T. ${ }^{2}-$ \\ BEISEMBAYEVA, M. A. ${ }^{1}-$ OSPAN, G. T. ${ }^{1}$ \\ ${ }^{1}$ Eurasian National University named after L. N. Gumilev \\ Astana 010000, Kazakhstan \\ ${ }^{2}$ Shakarim State University \\ Semey 071400, Kazakhstan \\ *Corresponding author \\ e-mail: ozgeldinova@mail.ru \\ (Received $5^{\text {th }}$ Nov 2016; accepted $20^{\text {th }}$ Jul 2017)
}

\begin{abstract}
Results of estimating geosystems'sustainability in conditions of anthropogenic impacts are presented in this work. The method for assessing the potential sustainability of geosystems in conditions of anthropogenic impact was improved and adapted. Integral assessment of the sustainability of geosystems of Sarysu Basin, Kazakhstan with regard to human impact by identifying landscape factors, allowed the differentiation of geosystems into 5 classes, requiring different approaches to the development of optimal environmental management structures.
\end{abstract}

Keywords: basin, landscape, sustainability, anthropogenic impact, geographic information systems

\section{Introduction}

The question of geosystem sustainability is becoming increasingly important in the case of increasing anthropogenic influence on the environment. Geosystems need to be researched, and to predict their conditions as a result of external factors to increase further production growth. The selection and implementation of the proper forecast methodology is only possible in static equilibrium systems. The development of the system in geosystems which are in a condition of crisis and in which an unstable equilibrium is emerging, can take an unpredictable path and lead to catastrophic consequences.

The concept of sustainability in physical geography has no clear definition. The definition depends on the purpose of assessment of natural or human-modified geosystems, which is given by different authors. All interpretations of this concept can be summarized in the following components: limits of natural functionality, ability to resist external influences (natural and anthropogenic), and ability to relax after load reduction (Chorley et al., 1971; Ryumin, 1990; Bastian et al., 2002). According to Sochava (1971), all the dynamic changes which take place within a single invariant (qualitatively unchanged) are an example of geosystem sustainability, because this represents the ability to restore to a previous condition or position. According to Ryumin (1990), a proper functioning of the system is linked with the phenomena of seasonal dynamics and has second importance in the definition of the sustainability. On the other hand, Isachenko (1980) emphasizes the role of dynamics in geosystems' sustainability. 
The research into geosystem sustainability in the face of anthropogenic pollution and the self-purification ability of technogenic materials plays an important role in landscape geochemistry (Solntseva, 1982; Glazovskaya, 1983; Volkova et al., 1987; Turner et al., 2001; Fu et al.,2013; Wu, 2013; Michaeli_et al., 2014). The stability of geosystems with regard to technogenesis is described by Glazovskaya (1997), via the self-purification ability. This ability is conditioned by the speed of transformation of man-made substances and their removal beyond geosystems (Glazovskaya, 1983). In many ways, this ability is possible owing to the compatibility of natural and man-made substance flows (Solntseva, 1982; Shadrina et al., 2014; Yermolaev et al., 2014; Michaeliet al., 2015).

Research into the sustainability of geosystems of the Sarysu Basin focuses on the increasing human impact on its environment. In this regard, the aim of the study of selected areas is determined by the necessity to obtain new landscape environmental information demanded for the future creation of the Sarysu Basin nature management strategy.

\section{Methods}

There is potential and real sustainability of the landscape. The first concept refers to the natural (undisturbed) condition; the second to a modern condition, absorbed by all layers that have accumulated in the history of human impact (Benson et al., 2007). However, it should be noted that the starting point for assessing the current sustainability of geosystems for forecasting development and work should be the initial variant, as the object of the basic landscape classification on the basis of its sustainability.

We analyse the geosystem's sustainability as the ability to maintain its structure and function under external impact. We used the principles of assessing the sustainability of the soil and the landscape, created by Glazovskaya (1997), Bashkin and Evstafieva (1993), and Orlova $(2002 ; 2006)$ (Table 1), to assess the sustainability of geosystems with regard to human impacts. These principles of assessment are based on normalizing methods of individual indicators, and their subsequent summation on a point system. They take into account the complex for an integrated assessment of sustainability of the whole group and geosystems, in terms of their overall sustainability (Table 1). The authors are fully aware that the proposed method of assessment of geosystem sustainability is only one of several possible practical approaches, which realization demands a lot to go through.

Table 1. The scale of mark estimation potential of landscape sustainability in conditions of anthropogenic impacts (compiled from materials of Glazovskaya (1997) Bashkin, Evstafieva (1993), Orlova 2002; 2006)

\begin{tabular}{l|l|l|l|l|l}
\hline Indicators & \multicolumn{5}{|c}{ Scores Of Sustainability } \\
\hline & $\mathbf{1}$ score & 2 score & 3 score & 4 score & 5 score \\
\hline $\begin{array}{l}\text { Radiation balance, } \\
\text { kcal/cm per year }\end{array}$ & $5-10$ & $11-20$ & $21-30$ & $31-50$ & $\begin{array}{l}\text { more than } \\
50\end{array}$ \\
\hline $\begin{array}{l}\text { Radiation index of } \\
\text { dryness }\end{array}$ & $\begin{array}{l}\text { less than } 0.45 \\
\text { and more than } \\
3\end{array}$ & - & 1.01. or 3.00 & - & $0.45-1.00$ \\
\hline $\begin{array}{l}\text { Wind conditions } \\
\text { (amounts of days } \\
\text { with strong wind) }\end{array}$ & more than 51 & - & $21-50$ & - & $0.45-1.00$ \\
\hline
\end{tabular}




\begin{tabular}{|c|c|c|c|c|c|}
\hline $\begin{array}{l}\text { Wind conditions } \\
\text { (amounts of days } \\
\text { with strong wind) }\end{array}$ & more than 51 & - & $21-50$ & - & less than 20 \\
\hline $\begin{array}{l}\text { Nature of the } \\
\text { landform }\end{array}$ & hilly & $\begin{array}{l}\text { hilly steeply } \\
\text { sloping } \\
\text { terrain }\end{array}$ & $\begin{array}{l}\text { gently hilly } \\
\text { terrain }\end{array}$ & $\begin{array}{l}\text { plateau and } \\
\text { slightly } \\
\text { wavy terrain }\end{array}$ & plain \\
\hline $\begin{array}{l}\text { Downhill gradient, } \\
\text { degree }\end{array}$ & more than 20 & $5.1-20$ & $3.1-5$ & $1.1-3$ & $0-1$ \\
\hline $\begin{array}{l}\text { Geochemical } \\
\text { location }\end{array}$ & accumulative & - & Transit & - & eluvial \\
\hline $\begin{array}{l}\text { The rate of natural } \\
\text { drainage }\end{array}$ & $\begin{array}{l}>0.0005 \text { very } \\
\text { poorly drained }\end{array}$ & \begin{tabular}{|l|}
\multicolumn{1}{|c|}{ a little bit } \\
poorly drained \\
$0,0005-$ \\
0,001 \\
\end{tabular} & $\begin{array}{l}\text { poorly drained } \\
0.001-0.008\end{array}$ & drained & $\begin{array}{l}\text { intensive } \\
\text { drained }\end{array}$ \\
\hline $\begin{array}{l}\text { Level of } \\
\text { hydromorphic soil }\end{array}$ & hydromorphic & 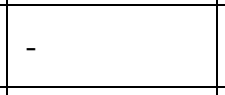 & $\begin{array}{l}\text { semi- } \\
\text { hydromorphic }\end{array}$ & - & automorphic \\
\hline Texture of soil & sand & clay sand & light loam & $\begin{array}{l}\text { medium } \\
\text { loam }\end{array}$ & heavy loam \\
\hline $\begin{array}{l}\text { Humus horizon } \\
\text { power, cm }\end{array}$ & less than 3 & $3-10$ & $10.1-25$ & $25.1-80$ & $\begin{array}{l}\text { more than } \\
80\end{array}$ \\
\hline $\begin{array}{l}\text { Humus content in } \\
\text { horizon } 0-20 \mathrm{~cm}, \%\end{array}$ & less 2 & $2.0-4.0$ & $4.1-6.0$ & $6.1-9.0$ & $\begin{array}{l}\text { more } \\
\text { than9.0 }\end{array}$ \\
\hline $\begin{array}{l}\text { Acidity status of the } \\
\text { soil }(\mathbf{p H})\end{array}$ & $\begin{array}{l}\text { very acid soil } \\
(4.5 \text { and less }) \\
\text { or very alkaline } \\
\text { soil ( } 8.5 \text { and } \\
\text { more) }\end{array}$ & $\begin{array}{l}\text { acid }(4.5- \\
5.0) \text { or } \\
\text { alkaline } \\
(7.5-8.5)\end{array}$ & $\begin{array}{l}\text { slightly acid } \\
\text { soil }(5.0-5.5) \\
\text { or slightly } \\
\text { alkaline soil } \\
(7.0-7.5)\end{array}$ & $\begin{array}{l}\text { near to } \\
\text { neutral }(5.5- \\
6.0)\end{array}$ & $\begin{array}{l}\text { neutral }(6.0- \\
7.0)\end{array}$ \\
\hline $\begin{array}{l}\text { Salinity (the } \\
\text { amount of salt in } \\
\text { the upper layer of } \\
\text { horizons, \%) }\end{array}$ & $\begin{array}{l}\text { highly saline } \\
\text { and very saline } \\
(0.6)\end{array}$ & $\begin{array}{l}\text { moderately } \\
\text { saline }(0.3- \\
0.6)\end{array}$ & $\begin{array}{l}\text { slightly } \\
\text { saline(0.2-0.3) }\end{array}$ & $\begin{array}{l}\text { very slightly } \\
\text { saline }(0.15- \\
0.2)\end{array}$ & $\begin{array}{l}\text { non-saline } \\
\text { (less than } \\
0.15 \text { ) }\end{array}$ \\
\hline $\begin{array}{l}\text { Cation exchange } \\
\text { capacity, mg.ekv } \\
\text { /100 gr. soil }\end{array}$ & less than 10 & $10-20$ & $21-30$ & $31-40$ & $\begin{array}{l}\text { more than } \\
40\end{array}$ \\
\hline $\begin{array}{l}\text { Type of water } \\
\text { regime }\end{array}$ & $\begin{array}{l}\text { desuctive- } \\
\text { exudational } \\
\text { regime }\end{array}$ & $\begin{array}{l}\text { exudational } \\
\text { regime }\end{array}$ & $\begin{array}{l}\text { non-leaching } \\
\text { regime }\end{array}$ & $\begin{array}{l}\text { periodically } \\
\text { leaching } \\
\text { regime }\end{array}$ & $\begin{array}{l}\text { leaching } \\
\text { regime }\end{array}$ \\
\hline Square canopy \% & Lesst han 20 & $20-40$ & $41-60$ & $61-90$ & $\begin{array}{l}\text { more than } \\
90\end{array}$ \\
\hline
\end{tabular}

We have to pay attention among climatic factors to some important factors determining energy flow in geosystems, such as radiation balance, irrigation adequacy, and wind conditions.

Radiation balance is determined by the relationship between the amount of energy reaching an object (or a portion of it) and the amount leaving it. The value of the radiation balance depends on many factors: latitude, surface properties and surface moistening, which have a direct impact on albedo and effective terrestrial radiation. The energy of the main biogenic and abiogenic processes in geosystemsis determined by radiation balance. According to Glazovskaya (1983), the speed and direction of chemical transformations of technological products is determined by radiation balance as well. Moreover, large parameters of radiation balance coincide with the maximum geosystem sustainability (under ceteris paribus) (Bashkin et al., 1993). 
The radiation index of the dryness value of dryness index characterizes the lack of moisture and is considered the lowest rate of sustainability (less than excessive moisture). From moisturizing performance, very informative radiation dryness index (K), the proposed M.I. Budyko (1984), which is the ratio between the radiation balance of the territory and the annual amount of precipitation, expressed in calories latent heat of vaporization, the equation $(E q .1)$ :

$$
K=R / L Q
$$

$R$ - radioactive balance per year, kilocalorie $/ \mathrm{cm}^{2}$ per year;

$L$ - latent energy of vaporization, kilocalorie $/ \mathrm{cm}^{2}$ per year;

$Q$ - annual amount of precipitation, $\mathrm{mm}$.

With $\mathrm{K}=1$ the possibility of vaporization is approximately around the amount of fallen humidity. This is relevant to conditions of maximum geosystem sustainability. With R/LQ less than 0.45 to 1 climate is called a damp climate, with $\mathrm{K}$ from 1 to 3 it is temperate climate, with $\mathrm{K}$ more than 3 it is an arid climate. Radiation index of dryness reflects water and humidity conservation with radiation conditions (Reymers, 1990).

The wind regime, on the one hand, is the factor of dispersion of artificially produced elements in the air, but on the other hand, it is also the factor of lateral (eolian) processes, and determines the adaptation features of biota. The number of days with strong wind per year are used as quality indicators to estimate the sustainability of geosystems.

The features of relief are used as an indicator which represents age and stage of development of the geosystem and compliance with endogenous and exogenous processes. Flat, uniform, slightly wavy and sleepy, sloping terrains have the highest degree of sustainability, whereas hilly terrains have the lowest one.

A steep slope plays an important role concerning geosystem sustainability, because an increase in steepness leads to more intense surface run-off, which increases the risk of the mechanical demolition of solid substances. Therefore this leads to the development of soil erosion. In addition, the speed of the real steep slope influences the speed of the real growth of the humus soil horizon, and the speed of the geosystem's recovery on slopes depends on thesteep slope. The angle of repose, the angle between the ground surface after land subsidence and floor sliding and the horizon are used to characterize the steep slope (Glazovskaya, 1997).

The important factor to determine the sustainability of geosystems from human impact is the determination of its geochemical position, which characterizes the nature and intensity of migration flows. Glazovskaya $(1983,1997)$ highlights three main types of gradation and two transition types, based on the classification of landscape types. Eluvial (watershed) landscapes are the most highly located, and are geochemically autonomous. They obtain their flow of material from the atmosphere. Transit landscapes are located on the lower stage of the cascade and geochemically are subordinates of elementary landscapes. This landscape obtains its flow of substitutes from the atmosphere and water release from surface and ground waters located higher than some stages of cascade. Accumulative landscapes are usually located on the flat areas near slopes, close to water bodies and floodplains, where there is an accumulation of substances. The accumulative landscapes located in the zone of storage of all incoming substances are the least stable. 
The level of natural drainage of geosystems leads to the process of accumulation or leaching out of chemicals. We used a method of evaluation of morphometric parameters of the basin created by Uglanov (1981), to calculate the natural drainage of geosystems (Eq. 2):

$$
\mathrm{P}=i \frac{H}{F}, i=\frac{h_{1}-h_{2}}{l}
$$

$P$ - natural drainage;

$H$ - the total length of all the elementary streams that are the basis of erosion (including their length) $\mathrm{km}$;

$F$ - area of the basin, $\mathrm{km}^{2}$; $i$ - main angle of site;

$h_{1}-h_{2}$ - height difference of elementary watercourse from its source to its mouth (depth oferosional dissection);

$l$ - watercourse length, $\mathrm{km}$.

The natural drainage classification, including the existing one but with some changes, was created by the authors during the analysis of the literature dedicated to drainage. Thus, geosystems are evaluated according the geosystems' sustainability to drainage: $\mathrm{P}$ 0.01-0.2 is very poorly drained; $\mathrm{P} 0.2-1$ is poorly drained; $\mathrm{P} 1-3$ is moderately drained; P 3-10 is well-drained; P 10 and higher is intensively drained.

Soil has a junction place, and forms a natural part of the ground cover's natural components. Indetermining the sustainability of the soil, we proceeded from the fact that it is formed by a buffer capacity (the ability to 'take on' neutralizing this effect, and due to external factors' ability to 'throw off' the load on to other ecosystems, due to the situation in catena, due to climate features) (Vasilevskaya et al., 1997). Next we used soil-geochemical indicators to assessthe sustainability of natural systems to human impact: the rate of hydromorphic soils, texture of soil, depth of humus horizons, the rate of soil acidity, and cation exchange capacity.

Next were groups of soil, depending on the location in the relief and the nature of hydration, called the rows of humidification: automorphic soil formed on flat surfaces and slopes in conditions of free surface water flow, with a deep water table (below $6 \mathrm{~m}$ ); semi-hydromorphic soil formed by the brief stagnation of surface water or groundwater occurring at a depth of 3-6 m (capillary fringe can reach the roots of plants); hydromorphic soils formed under conditions of prolonged stagnation of surface water or groundwater occurring at a depth of less than $3 \mathrm{~m}$ (capillary fringe may reach the soil surface). Rows of humidification of geosystems characterize the geochemical sustainability, which largely determines the intensity of the migration of chemical substances.

The texture of the soil is important for the soil's porosity, air and water permeability, hygroscopicity, absorption capacity, soil temperature, and others (Dobrovol'skiy, 1989). Loam and heavy loam have the best aforementioned indicators than sand and sandy loam.

The rate of soil sustainability to a variety of physical and mechanical stresses, and erosive and deflationary processes is determined by the depth of the humus horizons of the soil (Snakin et al., 1993). The content of humus in the soil largely determines the absorptive capacity of the soil and affects the formation of the structure of the upper soil layers and their physical features. Soils with high humus content can largely resist external impacts. 
The level of soil acidity (the reaction of medium, $\mathrm{pH}$ ) characterizes many genetic and industrial types of soil. Soils can react differently to pollution products depending on their acidic properties. The mobility of chemical elements and their chemical compounds can be changed in different environments.

The cation exchange capacity (CEC) (the amount of absorbed bases and hydrogen ions) is a crucial characteristic of the soil. It consists of the absorptive capacity of human substances, mineral soil particles, as well as the microorganisms that it includes. The value of soil CEC is correlated with the content of humus in it, the granulometric and mineralogical composition and the level of $\mathrm{pH}$. Soil has a buffering capacity depending on the amount of soil ionic exchange. Hence it has different resistance to external effects (Bashkin et al., 1993).

The type of water regime characterizes the geochemical sustainability of the soil, which is largely determined by the intensity of the removal of substances outside this landscape, the rate of scattering these to the surface, as well as underground drainage and air flow. Based on the classification of types of water regime, Vysotsky and Rode (1965) is necessary to allocate: leaching type and periodical leaching regime (as an intermediate form), non-leaching, and exudative and desuctive-exudational (or stagnation). Leaching type leads to the removal of pollution products; exudative, desuctive-exudational regimes lead to an accumulation of pollution products in the soil profile.

The canopy also helps to reduce soil degradation from erosion. Geosystems covered with a large area of canopy are more resistant to external impact than areas without canopy.

Integral assessment of the sustainability of geosystems to human impacts was obtained by summing the ratings analysed parameters within the operating units of study, which in our work is the landscape. It is based on previously made contact medium-scale landscape map (1:5000 of the Sarysu Basin (Figure 1; Table 2), which allocated 58 individual landscapes as a result of its typological groups, and also based on the result of the following structural-genetic classification, where groups are arranged in a hierarchical taxonomy: class (plain and mountain landscapes), types (semi-desert and desert landscapes), subtypes (north-desert and south-desert landscapes).

The maximum possible score that characterizes the highest relative sustainability for the area was set at 100\%; all other points are expressed as a percentage, which was carried out by recalculating the total points according to the equation presented in Orlova (2002). See equation (Eq. 3):

$$
C=\frac{100 \sum_{g=1}^{\mathrm{n}} C_{g}}{Q}
$$

$C$ - Assessment of potential sustainability of geosystems to anthropogenic influences, $\%$;

$\mathrm{Cg}$ - score for each indicator;

$Q$ - maximum possible amount of points;

$g$ - serial number indicator;

$n$ - number of indicators. 
As a result, the following were identified as a Geosystems Group, where grading was based on the total points (\%): relatively sustainability geosystems, 100-90; average sustainability, 90-80; weak sustainability, 80-70; low sustainability. less than 70 .

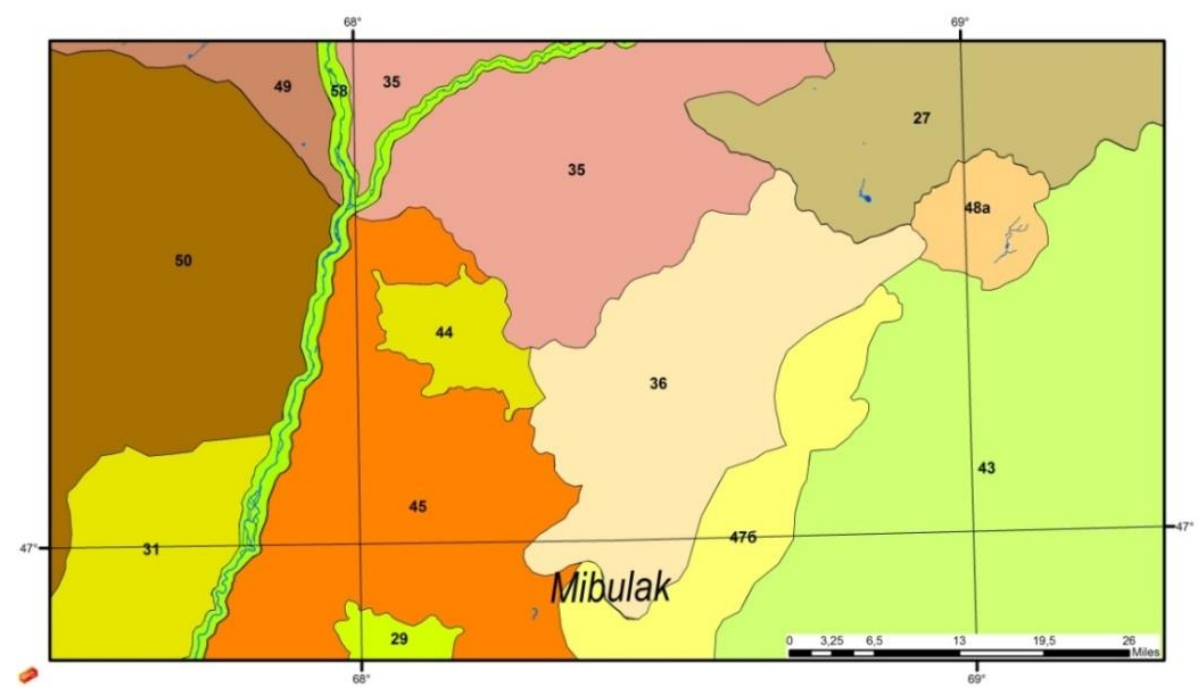

Figure 1. Landscape map of Sarysu Basin, Kazakhstan (fragment)

\section{Results}

According to the integral estimation of geosystem sustainability we could define that geosystems with the relatively degree of sustainability (landscapes 12, 14, 25, 26, 27, 33, 35,57 ) spread over $19.69 \%$ of the basin. Geochemical landscapes have an eluvial position with two rather different major landforms: hilly terrain with different slopes (especially $2-6^{\circ}$ ); and geosystems characterized by relatively favourable thermal and hydrothermal conditions. Dominated by medium and heavy loam automorphic soils, characterized by a non-leaching water regime, non-saline and with neutral or close to neutral the reaction of the soil solution. The humus content inthe layer of $0-20 \mathrm{~cm}$ is on average $2.3 \%$, humus horizon is around 12-38 cm. The Cation Exchange capacity is around 16-17 mg.ekv /100 gr. soil. The canopy area is around $70-75 \%$ (Table 3; Figure 2).

Table 2. Keywords for fragment of Sarysu Basin's landscape map (№ by map Figure 1)

\begin{tabular}{|c|c|}
\hline № & The name of landscapes \\
\hline $\mathbf{I}$ & $\begin{array}{c}\text { Plain landscapes } \\
\text { Semi-desertic } \\
\text { 2 Aggraded plains } \\
27 \text { - Diluvial-proluvial slightly inclined plain with riverbed temporary streams } \\
\text { formed by volcanic sedimentary rocks with artemesia-stipa flora on light-brown } \\
\text { normal soils. }\end{array}$ \\
\hline II & Desert \\
\hline $\mathbf{a}$ & North desert \\
\hline
\end{tabular}




\begin{tabular}{|c|c|}
\hline 1 & $\begin{array}{c}\text { Denudation plains } \\
29 \text { - Rolling-wavy socle plain with closed basins and erosional outliers formed by } \\
\text { clays, sandstones, sands with grass-Salsolaarbusculiformi, anabasis salsa and tas- } \\
\text { anabasis-salsa flora on brown desert soils. } \\
31 \text { - Gently inclined slightly undulating plain with small sand ridges formed by } \\
\text { clays, loams, standstones with Salsolaarbusculiformi, anabasis salsa and tas- } \\
\text { anabasis-salsa flora on brown desert soils. } \\
35 \text { - Dissected plain built on horizontal strata with closed basins and erosional } \\
\text { outliers formed by limestones, dolomites, sandstones with artemesiatas-anabasis- } \\
\text { salsa flora on brown desert soils. }\end{array}$ \\
\hline 2 & 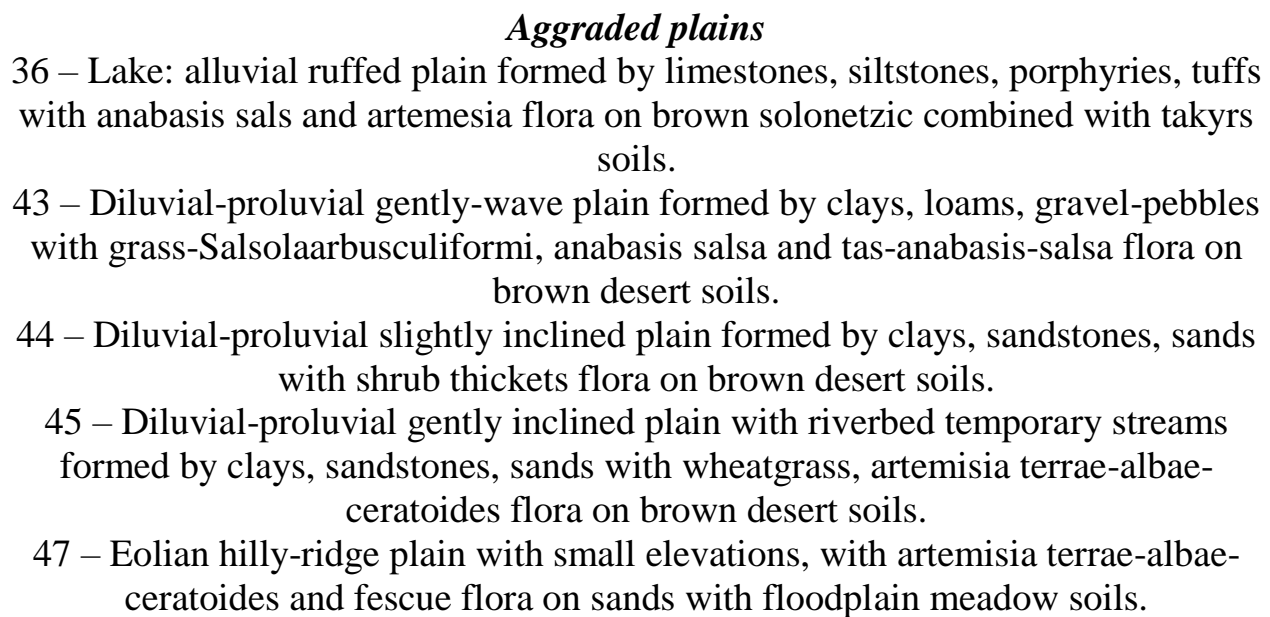 \\
\hline б & $\begin{array}{l}48 \text { - Eolian hilly plain with small elevations with white wormwood-fescue and } \\
\text { wheatgrass and grey artemisia flora on the sands with floodplain meadow soils }\end{array}$ \\
\hline 1 & $\begin{array}{c}\text { Southern Desert } \\
\text { Denudation plains } \\
49 \text { - Rolling-wavy socle plain with closed basins and erosional outliers with } \\
\text { anabasis salsa and artemesia flora on solonetz. } \\
50 \text { - Undulating plain with closed basins and erosional outliers with grass- } \\
\text { Salsolaarbusculiformi, anabasis salsa and tas-anabasis-salsa flora on brown desert } \\
\text { soils with solonetz. }\end{array}$ \\
\hline
\end{tabular}

Geosystems which have an average degree of sustainability occupied $35.68 \%$ of the basin (landscapes 1, 2, 3, 4, 7, 10, 13, 15, 16, 18, 19, 21, 29, 31, 45, 49, 55, 55b, v). Mostly they are hilly and uplands-ridged-sloping plains with low mountain terrain. The geochemical geosystems have an eluvial position with different surface slopes (mostly $\left.0-5^{\circ}\right)$ and low mountain $\left(4-21^{\circ}\right)$ dominated by medium and light loam automorphic soils, characterized by a leaching water regime, slightly saline, and with neutral or slightly acidic and slightly alkaline reaction of the soil solution. The humus content in the layer of $0-20 \mathrm{~cm}$ is around $2.1 \%$, humus horizon is around $15-20 \mathrm{~cm}$. The cation exchange capacity is around 15-16 mg.-ekv / 100gr soil. Hollow sleepy sloping plain is almost completely ploughed up, and uplands-ridged low mountains have an average degree of canopy. 
Table 3. Sustainability indicators of geosystems of Sarysu Basin in conditions of human impacts (1-4 of 58 indicator fragments)

\begin{tabular}{|c|c|c|c|c|c|c|c|c|c|c|c|c|c|c|c|c|}
\hline 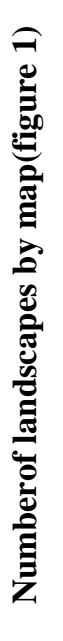 & 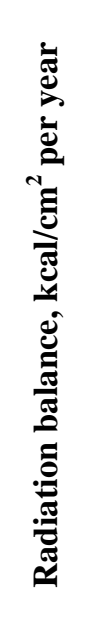 & 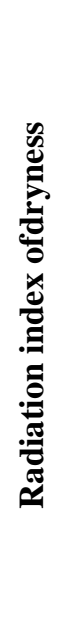 & 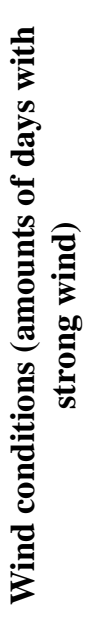 & 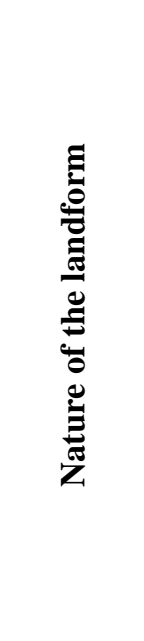 & 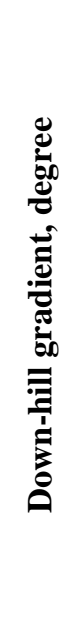 & 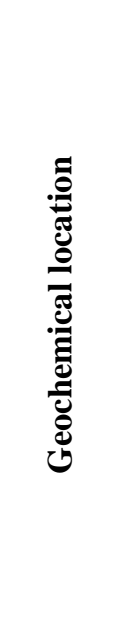 & 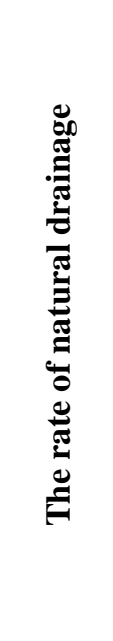 & 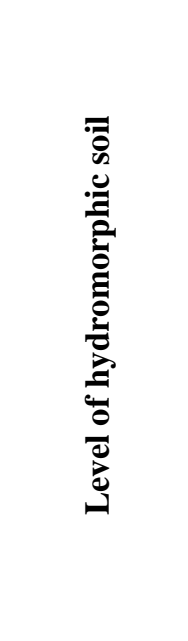 & 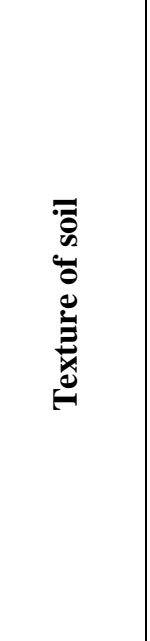 & 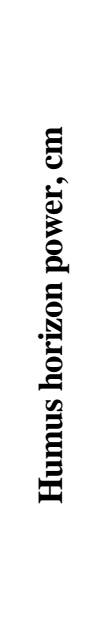 & 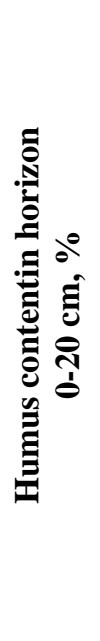 & 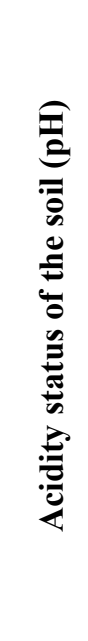 & 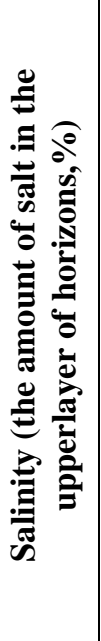 & 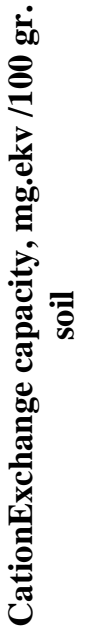 & 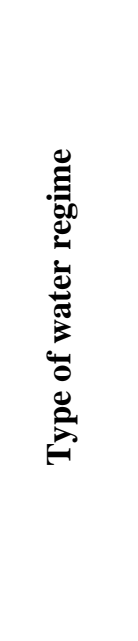 & 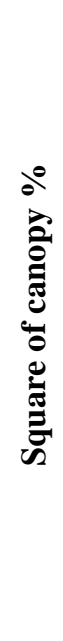 \\
\hline 1 & 29.01 & 5.2 & 13 & $\begin{array}{c}\text { ruefully- } \\
\text { hilly }\end{array}$ & 3.5 & eluvial & 0.008 & automorphic & lightloam & $9-10$ & 2.3 & 8.2 & 0.09 & 17.5 & $\begin{array}{l}\text { non- } \\
\text { leaching } \\
\text { regime }\end{array}$ & 30 \\
\hline 2 & 28.68 & 4.7 & 26 & $\begin{array}{l}\text { ridge-- } \\
\text { arched }\end{array}$ & 3.9 & eluvial & 0.0007 & automorphic & lightloam & $9-10$ & 2.4 & 7.8 & 0.04 & 13 & $\begin{array}{l}\text { non- } \\
\text { leaching } \\
\text { regime }\end{array}$ & 65 \\
\hline 3 & 29.06 & 4.9 & 13 & $\begin{array}{c}\text { ruffed- } \\
\text { hilly }\end{array}$ & 2.9 & eluvial & 0.008 & automorphic & lightloam & $9-10$ & 2.1 & 7.6 & 0.04 & 13 & $\begin{array}{l}\text { non- } \\
\text { leaching } \\
\text { regime }\end{array}$ & 70 \\
\hline 4 & 29.01 & 5.2 & 13 & ruffed & 3.5 & eluvial & 0.008 & automorphic & lightloam & $9-10$ & 2.3 & 8.2 & 0.09 & 17.5 & $\begin{array}{l}\text { non- } \\
\text { leaching } \\
\text { regime }\end{array}$ & 30 \\
\hline
\end{tabular}


Geosystems which have a weak degree of sustainability occupied $41.26 \%$ of the basin (landscapes 5, 8, 9, 11, 17, 24, 28, 30, 32, 34, 36, 42, 43, 50, 51). The geochemical geosystems has a transit and accumulative position mainly with flat terrain and slopes of surface of around $2^{\circ}$, dominated by hydromorphic loamy and sandy loam soils, characterized by an exudative water regime, moderately saline, and with an alkaline reaction of the soil solution. Depending on the type of soil humus content can change in the layer of $0-20 \mathrm{~cm}$ in the scope of values reaches 10.5 and is $1.5-12 \%$, humus horizon is around $10-11 \mathrm{~cm}$. The cation exchange capacity is around $15 \mathrm{mg}$.ekv./100 gr. soil. The canopy area is around 55-65\%.

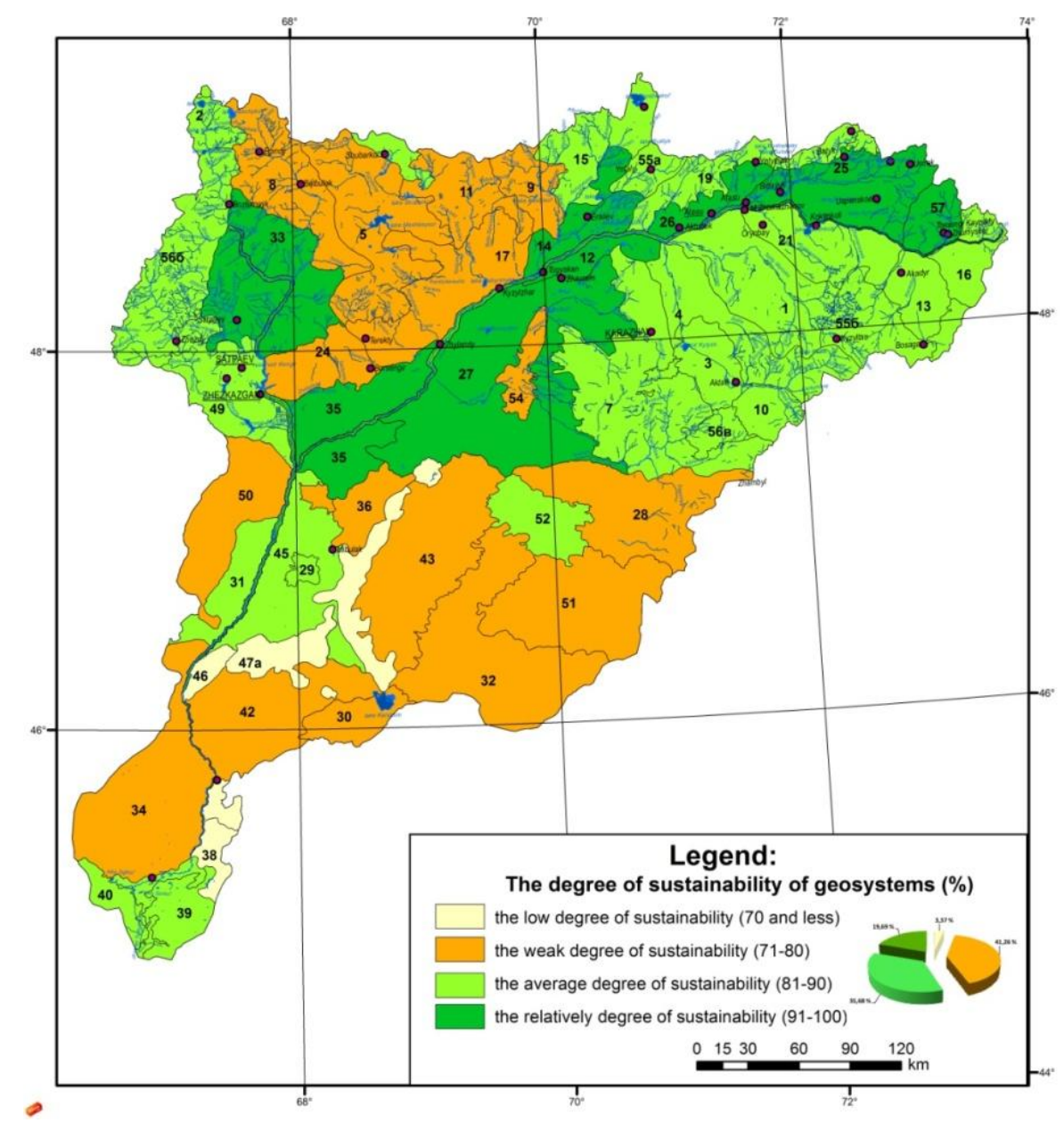

Figure 2. Map of landscape sustainability of Saursu Basin, Kazakhstan in conditions of human impact

The last group of geosystems (landscapes 46-48) was determined like those with a low to anthropogenic impact. They are hilly-ridged Aeolian plains with wheatgrass, artemisia terrae-albae-ceratoides vegetation on the sand, and floodplain meadow soils. The geosystems mainly have an accumulative position with flat relief and slopes around $0-2^{\circ}$. Sandy hydromorphic soils have a desuctive-exudational water regime, moderately saline, and an alkaline reaction of the soil solution. The humus content in the layer of 0 $20 \mathrm{~cm}$ is around $0.3-0.4 \%$, humus horizon is around $5-7 \mathrm{~cm}$. The cation exchange capacity is around 16-17 mg.-ekv/100 gr. soil. The canopy area is around 25-30\%. 
In general, geosystems with a low degree of sustainability (41.26\%) and an average degree of sustainability (35.68) dominate the study area. In the future, information about geosystems, obtained via the assessment of sustainability will be interpreted from the standpoint of commercial geography, to develop the optimum environmental management structure. This structure includes information about the status of the potential sustainability of geosystems with regard to human impact, and the level of anthropogenic load on geosystems. Sustainability is regarded as a special natural resource because it an environmental assimilation capacity environment concerning the emission of substances and energy. Moreover, it can be used as an indicator to determine environmental policy during human impacts. It is assumed that the optimum environmental management structure does not lead to negative consequences, and does not reduce geosystems' features of resource and environmental forming. On the other hand, imperfect environmental management formed without the landscape features of the territory leads to disruption and degradation.

\section{Conclusions}

The Sarysu Basin region is a closed drainage basin with poor biodiversity eroded by aquatic, but also the strength of intensive and direct air links. The Basin is located mainly within desert and semi-desert landscape zones. The Basin's geosystems have a combination of natural factors, which strengthen the pollution of geosystems. Hence it cuts down the centralization, streamlining, self-organization and sustainability of the landscape.

The integral evaluation of the level of sustainability of natural complexes to anthropogenic impacts by identifying landscape factors of the geosystems allows the identification of landscapes with different levels of sustainability potential (from relatively stable to weakly stable). It demands different approaches in the development of environmental management structures. The research identified geosystems with sustainability relative to human impact located at the Sarysu flow in the upper steam. The upper steam geosystems are eluvial and have favourable thermal and hydrothermal conditions, whereas geosystems located at the flow subsidence are accumulative, with low resilience.

Acknowledgements. Supported by EFOP-3.6.1-16-2016-00001.

\section{REFERENCES}

[1] Bashkin, V. Evstafieva, E., Snakin, V. (1993): The biochemical bases of environmental regulation. - Russian Academy of Sciences, Moscow, pp. 201-205.

[2] Bastian, O.B., Steinhardt, U.S. (2002): Development and Perspectives of Landscape Ecology. - Kluwer Academic Publishers, Dordrecht, Boston, London, pp. 567-569.

[3] Benson, J., Roe, M. (2007): Landscape and Sustainability. - Taylor \& Francis e-Library, London, pp. 112-115.

[4] Budyko, M. (1984): The evolution of the biosphere.- Gidrometeoizdat, Leningrad, pp. 1518.

[5] Chorley, R., Kennedy B. (1971): Physical geography, a system approach. - London: Prentice-Hall International, pp. 194-195. 
[6] Dobrovol'skiy, V. (1989): Geography of soils with the basics of soil science: the textbook for universities.- VLADOS, Moscow, pp. 186-189.

[7] Fu, B. and Jones, K. B. (2013) Landscape ecology for sustainable environment and culture, Landscape Ecology for Sustainable Environment and Culture. doi: 10.1007/97894-007-6530-6. - Springer Science, Beijing, pp. 115-118.

[8] Glazovskaya, M. (1983): Principles of classification of natural geosystems' resistance to technogenic and predicted landscape-geochemical zoning. - Science, Moscow, pp. 61-78.

[9] Glazovskaya, M. (1997): The methodological bases of estimation of ecologicaland geochemical soil resistance to anthropogenic impacts. - Science, Moscow, pp. 54-58.

[10] Isachenko, A. (1980): Optimization the natural environment.- Mysl, Moscow, pp. 68-71.

[11] Ivanova, M. / Michaeli, E. / Solar, V. / Cech, V. (2014): The ecological stability evaluation of the landscape (case study from the eastern slovakia). - In: 14th SGEM GeoConference on Ecology, Economics, Education And Legislation 2: 57-89.

[12] Michaeli, E., Ivanova, M., Solar, V., Cech, V. (2014): The ecological stability evaluation of the landscape. - Geoconference on Ecology, Economics, Education and Legislation 1: 695-702.

[13] Michaeli, E., Ivanova, M., Koco, S. (2015): The evaluation of anthropogenic impact on the ecological stability of landscape. - Journal of Environmental Biology 1: 1-7.

[14] Orlova, I. (2002): Landscape planning for agricultural nature management purposes.Institute of Water and Environmental Problems,- Barnaul, pp. 22-25.

[15] Orlova, I. (2006): Landscape planning for the purposes of a balanced using agricultural nature. - Geography and Natural Resources 2: 121-134.

[16] Reymers, N. (1990): Nature Management: Dictionary-Directory. - Mysl, Moscow 1, p.637.

[17] Rode, A. (1965): The water regime of the soil and its regulation.- The USSR AN, Moscow, pp.86-88.

[18] Ryumin, V. (1990): Approaches to rationing structure anthropogenic landscapes. - The USSR AN6 Irkutsk 1(1) : pp. 76-78.

[19] Shadrina, E., Vol'pert, Y. (2014): Developmental instability of the organism as a result of pessimization of environment under anthropogenic transformation of natural landscapes. - Russian Journal of Developmental Biology 3: 117-126.

[20] Snakin, V., Mel'chenko, V., Krechetov, P. (1993): Evaluation of the sustainability of ecosystems.- Institute of Nature Conservation in Moscow 1: 196-211.

[21] Sochava, V. (1971): Theoretical background mapping habitat. - Institute of Geography Sibiri i Dal'negoVostoka 34: 3-14.

[22] Solntseva, N. (1982): The geochemical sustainability of natural systems to technogenicstress. - The USSR AN 1: 181-216

[23] Turner, M., Gardner, R., O'Neill, R. (2001): Landscape Ecology in Theory and Practice: Pattern and Process.- Springer, New York, pp. 153-162. doi: 10.1007/BF00131534

[24] Uglanov, I. (1981): Reclaimed soil and rock strata south of Western Siberia.- Institute of Nature Conservation in Moscow 2:14-16.

[25] Vasilevskaya, V., Kalisheva, O., Koptsik, G. (1997): The sustainability of soils of nearMoscow suburbs to anthropogenic influences. - Bulletin of Moscow University 3: 36.

[26] Volkova, V., Davydova, N. (1987): Technogenesis and transformation of landscapes. Nauka, Novosibirsk 1: 47-49.

[27] Wu, J. (2013): Landscape sustainability science: ecosystem services and human wellbeingin changing landscapes. - Landscape Ecology 6: 999-1023.

[28] Yermolaev, O., Usmanov, B. (2014): The basin approach to the anthropogenic impact assessment in oil-producing region.- Nauka, Moscow 2: 681-688. 